\title{
POTENCIAL DE CONTAMINAÇÃO DE AQUÍFERO FREÁTICO POR ESGOTO DOMÉSTICO - QUANTIFICAÇÃO DO DECAIMENTO BACTERIOLÓGICO
}

\author{
Virginia Maria Tesone Coelho ${ }^{1}$ e Uriel Duarte ${ }^{2}$
}

\begin{abstract}
RESUMO
Esta pesquisa, para fins de determinação do comportamento de microrganismos termotolerantes em águas de aqüífero freático, foi realizada em terrenos aluviais na Estação de Tratamento de Esgotos de Vila dos Remédios, Salesópolis - SP. No local foi instalada uma vala de infiltração para esgoto doméstico bruto e foram instalados 55 poços de monitoramento da água subterrânea, de modo a caracterizar a pluma de contaminação em seu deslocamento ao longo da área ensaiada. Seguindo as normas técnicas de coleta e análise físico-química-bacteriológica das águas subterrâneas foram executadas, com o intuito de conhecimento específico do local de pesquisa, 55 poços com amostragem e caracterização litológica do solo local até profundidade de 2,0 metros, prospecção geofísica eletrorresistiva de caracterização inicial e eletromagnética (EM-31) de acompanhamento do deslocamento da pluma de contaminação, amostragem e caracterização físico-química-bacteriológica do esgoto bruto e das águas subterrâneas. Dois mil litros de esgoto bruto, coletado diretamente da rede, foi introduzido no solo através de vala de infiltração, de modo a caracterizar uma injeção pontual, sem transbordamento e de maneira contínua, com uma taxa de infiltração de aproximadamente $80 \mathrm{~L} / \mathrm{h}$. O deslocamento da pluma de contaminação formada no aqüífero freático saturado foi monitorado através de amostras de água coletadas sistematicamente, ao longo do tempo, cujos resultados permitiram calcular a velocidade de deslocamento da pluma, como sendo de 7,67 x $10^{-4} \mathrm{~cm} / \mathrm{s}$ e, um decaimento de organismos termotolerantes em ambiente de aqüífero saturado de 21 dias. Estes resultados permitem o cálculo direto de perímetros de proteção aplicáveis a poços e fontes naturais de captação de água subterrânea, no caso de possibilidades de contaminação por esgoto domiciliar, neste contexto litológico.
\end{abstract}

Palavras-chave: decaimento bacteriológico; coliformes fecais; contaminação freática

\begin{abstract}
The objective of this research was to study the behavior of thermo-tolerant microorganisms in the shallow aquifer, in alluvial terrains where the sewage was disposed. The study area was close to the sewage treatment plant of Vila dos Remédios, Salesópolis, SP. An injection trench and 55 monitoring wells were installed in the area. The sewage was discharged in the trench and samples of the groundwater were taken to study the contamination plume migration and its physico chemical and bacteriological characteristics in time. The wells were installed 2.0 meters deep and the samples were used to characterize the lithological setting. An initial electroresistivity survey was performed and, along with the groundwater sampling, electromagnetic survey (EM-31) was periodically conducted to evaluate the plume migration. Two thousand liters of domestic sewage "in natura" was introduced into the trench to characterize a punctual injection, with a continuous infiltration rate of $80 \mathrm{~L} / \mathrm{h}$. The migration of the contamination plume was continuously monitored during nine months and the results allowed calculating the migration speed as being $7,67 \times 10^{-4} \mathrm{~cm} / \mathrm{s}$. The thermo-tolerant microorganisms were extinguished 21 days after the sewage injection. These results allow calculating the protection perimeter applied to groundwater wells and natural springs to avoid sewage contamination in the same lithological context.
\end{abstract}

Keywords: bacteriologic decay; fecal coliforms; aquifer contamination

\section{INTRODUÇÃO}

Estudos e pesquisas aplicadas mostram que o controle da poluição, o aproveitamento racional das fontes de energia e a implantação de saneamento são sistemas de defesa desenvolvidos por comunidades que, instintivamente, buscam sua autoconservação.

Um dos sistemas de defesa de grande importância para proteção e preservação do meio ambiente é o saneamento, que constitui condição essencial ao bem estar humano, além de exercer grandes implicações na economia produzindo novas riquezas com o surgimento de atividades industriais ligadas ao setor.
Afastar os esgotos das imediações das moradias, pouco contribui para a qualidade de vida de uma população, o ideal é implantar sistemas adequados de tratamento e disposição.

O tratamento visa confinar os microrganismos patogênicos para destruí-los ou reduzi-los a valores sanitariamente seguros, evitando a transmissão de doenças e degradação ambiental.

Nenhum sistema de tratamento pode ser indicado como ideal para qualquer situação. Somente quando se escolhe criteriosamente um processo que se adapte às condições e aos objetivos de cada local pode-se obter uma boa relação custo/ benefício.

\footnotetext{
${ }_{1,2}$ Instituto de Geociências da Universidade de São Paulo - Rua do Lago, $n^{\circ} 562$ - Cidade Universitária - CER: 05508-080 São Paulo - SP - Brasil

I'vmcoelho@usp.br)

2(urduarte@usp.br)
} 
A tecnologia de tratamento de efluente doméstico com infiltração no solo é utilizada em muitos países, inclusive o Brasil, que, desde a década de 1980, estuda esse tipo de metodologia direcionada à aplicação em comunidades, pois a prática de infiltrar esgotos no solo sempre existiu

A falta de rede de esgoto conduz à utilização de tratamento unifamiliar através do uso de fossas sépticas.

Projetosexperimentais deestações detratamento de esgotos por infiltração vêm se desenvolvendo nos últimos anos, e entre eles, destaca-se a Estação de Tratamento de Esgotos Vila dos Remédios, implantada no município de Salesópolis - SP que, dentro de uma visão integrada dos sistemas de água e esgotos, atende às necessidades de tratamento sem o comprometimento da qualidade dos recursos hídricos e do meio ambiente.

O sistema de tratamento possui adaptações com o propósito de aumentar a evaporação do líquido, diminuindo a quantidade de efluente infiltrado, permitindo a mineralização do esgoto antes que este se transforme em fonte de contaminação das águas do aqüífero.

O tratamento tem início na calha de retenção de sólidos e gorduras, seguido de lagoa facultativa primária (aeróbia) com posterior infiltração no solo por meio de drenos superficiais, assentados sobre uma camada de brita favorecendo a oxigenação e evaporação, o que não é considerado em metodologias similares.

Os efluentes domésticos, quando infiltrados no solo, depuram-se naturalmente contribuindo com a recarga do aqüífero, porém, o alto risco de contaminação das águas subterrâneas exige um controle rigoroso desses sistemas para que não ocorram problemas ambientais e risco à saúde pública.

Partindo desta preocupação, a pesquisa foi idealizada com o intuito de subsidiar sistemas de disposição de efluentes e cálculo de perímetros de proteção para fontes e poços rasos/profundos de captação de água para abastecimento. Este estudo verificou o decaimento natural de microrganismos indicadores de contaminação por esgoto doméstico em aqüífero freático saturado, em função do tempo de trânsito do efluente nas águas subterrâneas, com base na condutividade e gradiente hidráulicos, através de dados reais de experiência de campo, com a infiltração direta do efluente bruto oriundo da rede coletora.

\section{INDICADORES DE CONTAMINAÇÃO FECAL EM ÁGUAS}

Determinar a presença de todos os organismos patogênicos implicados nos processos de contaminação de águas é extremamente difícil, tendo em vista a necessidade de tempo para análises, laboratórios especializados e alto custo. Esta dificuldade viabilizou a implantação da metodologia que utiliza organismos indicadores como meio de avaliação rápida e confiável, para determinar a presença de patógenos na água (CAMPOS, 1999).

Os organismos indicadores são aqueles que possuem um comportamento similar aos patogênicos (concentração e reação frente a fatores ambientais e barreiras artificiais), porém, são mais rápidos, econômicos e fáceis de serem identificados. Uma vez detectados pode-se inferir que os patogênicos encontram-se também presentes.

O microrganismo indicador deve reunir as seguintes características:

- Ser constituinte da flora intestinal de indivíduos sãos.

- Estar presente, exclusivamente, nas fezes de animais homeotérmicos.

- Estar presente quando existir patógenos intestinais.

- Apresentar-se em número elevado, facilitando seu isolamento e identificação.

- Ser incapaz de se reproduzir fora do intestino dos animais homeotérmicos.

- Resistir aos fatores ambientais de forma igual ou superior aos patógenos de origem fecal.

- De fácil isolamento e quantificação.

- Não deve ser patogênico.

Nenhum microrganismo reúne todos os critérios de um indicador ideal, mas alguns grupos satisfazem parte dos requisitos (MADIGAN et al., 1997). É, portanto, necessário definir o que é importante e qual será o uso da água para a escolha de um ou mais indicadores a serem analisados.

Asbactériasdogrupocoliformesãoconsideradas os principais indicadores de contaminação fecal, destacando-se entre estes microrganismos, as bactérias do subgrupo coliformes fecais que têm maior representatividade para contaminação por esgotos domésticos. São bactérias entéricas que colonizam o trato gastrintestinal do homem e são eliminadas através das fezes em grandes 
concentrações.

Adeterminação da concentração dos coliformes fecais assume importância como parâmetro indicador da possibilidade da existência de microrganismos patogênicos, responsáveis pela transmissão de doenças de veiculação hídrica.

Os coliformes fecais pertencem à família Enterobacteriaceae, são bastonetes Gramnegativos não formadores de esporos que se desenvolvem ativamente à temperatura de $44,5^{\circ} \mathrm{C}$, por isso são denominados termotolerantes (PELCZAR et al., 1980). Nas fezes de animais homeotérmicos, sua concentração é em média $10^{8}$ a $10^{10}$ células por grama.

As bactérias do gênero Escherichia coli atendem os pré-requisitos de um bom indicador de contaminação fecal, principalmente porque é constituinte normal da flora intestinal de animais de sangue quente, como o homem, compõem $90 \%$ do total de coliformes fecais que um indivíduo libera por dia ( $10^{9}$ bactérias por grama de fezes), é de fácil e rápida detecção (CEBALLOS, 2000).

A linhagem Escherichia coli enteropatogênica, causadora de infecções intestinais, corresponde a menos de $1 \%$ da população dessa espécie em águas poluídas.

Embora de grande praticidade, o teste de coliformes não garante a ausência de outros patógenos mais resistentes nas águas que as bactérias.

Nos últimos dez anos, a evolução da Microbiologia Ambiental e Sanitária experimentou grande progresso em função das tecnologias emergentes devido à crescente preocupação com o potencial patogênico das águas de consumo.

Atualmente, outros microrganismos já estão sendoutilizados como indicadores de contaminação fecal como Campylobacter, Aeromonas (ROSE, 1990) e Yersinia enterocolítica que são bactérias patogênicas ou potencialmente patogênicas expelidas com as fezes (WESCOTT, 1990).

A bactéria Clostridium perfringens, quando presente em águas, está constantemente associada a dejetos humanos; por serem esporuladas, são resistentes à desinfecção e às condições adversas do meio e a longevidade de seus esporos em águas, propicia a detecção de contaminação fecal remota, em situações em que indicadores menos resistentes, como a Escherichia coli, não estão mais presentes (DANIEL, 2001).

Parasitas encontrados com freqüência em indivíduos infectados foram sugeridos como bons indicadores de contaminação fecal em águas, tais como ovos de helmintos (Ascaris lumbricoides) devido às seguintes vantagens apresentadas: persistência no meio ambiente por vários meses sem se multiplicar; é de fácil identificação; o índice de parasitismo é mundialmente elevado; e, o risco de transmissão é muito alto (grande concentração de ovos).

Outros parasitas como os protozoários entéricos são reconhecidos como causadores de surtos infecciosos transmitidos pelas águas. Os protozoários mais comuns nas fezes humanas são: Giárdia lamblia, Entamoeba histolitica e Balantidium coli, mais recentemente, foram identificados gêneros de Cryptosporidium (MADIGAN et al., 1997).

Os vírus, que estão presentes somente nas fezes de indivíduos infectados, são mais resistentes às desinfecções que as bactérias (indicadores tradicionais de contaminação), por conseguinte, não são detectados com eficiência, pelos testes tradicionais de determinação de contaminação fecal em águas. A quantidade de vírus entéricos nas águas é muito variável e sua detecção requer tempo e custo elevados, assim, foi necessário buscar um indicador alternativo de rápida detecção e baixo custo que permitisse prever o comportamento dos enterovírus no meio ambiente. Estes indicadores são os fagos (SCHWARTZBROD, 1995).

Os colifagos somáticos e os bacteriófagos F-especificos são bons representantes para indicar contaminação fecal, pelo fato de relacionaremse diretamente com seu hospedeiro bacteriano (Escherichia coli) e estarem freqüentemente presentes nas amostras onde a $E$. coli é isolada. Por serem mais resistentes são utilizados na avaliação da qualidade da água com a vantagem de fornecerem resultados após um tempo mínimo de 4 a 6 horas (KOTT et al., 1978; BORREGO et al., 1987; YATES, 1992).

\section{TRANSPORTE E SOBREVIVÊNCIA DE MICRORGANISMOS NO SUBSOLO}

Os primeiros estudos sobre transporte de contaminantes microbiológicos no solo, utilizandose bactérias como traçadores foram realizados na década de 10 , evoluindo mais nas décadas de 30 e 50 com a ampliação dos conhecimentos em virtude dos estudos de viabilidade para a injeção de efluentes de esgotos domésticos e industriais em solos. 
É difícil fazer generalizações a respeito da distância percorrida por microrganismos no solo, porém, o movimento está relacionado diretamente com os valores de carga hidráulica e inversamente com o tamanho das partículas de solo e da concentração e composição catiônica do soluto. A retenção e a pressão de oxigênio, a temperatura, a disponibilidade de alimento, as formas antagônicas da microflora do solo, o grau de saturação do solo, o pH, a insolação, o conteúdo de matéria orgânica e a concentração inicial de bactérias.

Também são relativamente limitadas as informações sobre a sobrevivência de bactérias em águas subterrâneas. Em geral, tem-se como pacífica a teoria de que o período de sobrevivência desses organismos, de forma geral, é mais longo em águas subterrâneas do que em águas superficiais, em virtude da ausência de luz do sol e da baixa intensidade de competição por nutrientes disponíveis. Da mesma forma, a temperatura constitui-se num fator importante, com as bactérias sobrevivendo por maior tempo a temperaturas mais baixas.

A natureza química das águas subterrâneas também afeta a capacidade de sobrevivência de qualquer bactéria presente. Bactérias entéricas, em geral, apresentam dificuldades de sobrevivência em condições ácidas e em graus variáveis, ocorrendo o mesmo em águas subterrâneas salobras.

As bactérias entéricas sobrevivem em águas subterrâneas por períodos de tempo consideráveis (cem dias ou mais), dependendo da temperatura. Em países mais quentes, a temperatura das águas subterrâneas rasas (nível freático) é relativamente elevada. Assim, o período de sobrevivência de microorganismos entéricos deve ser menor nas águas subterrâneas de países tropicais do que daqueles temperados. Todavia, a possibilidade da reprodução deve ser levada em consideração, na medida em que é sabido que diversos tipos de bactérias podem se desenvolver e se reproduzir em águas que contenham sais minerais e uma fonte de energia (LEWIS, 1986).

Antes dos anos cinqüenta, os estudos de microrganismos patogênicos nas águas subterrâneas restringiam-se apenas à qualidade da água, ou seja, a verificação de ocorrências dos organismos. A partir desta década, surgiram os primeiros esforços, para compreender os mecanismos de movimento das bactérias e vírus nas águas subterrâneas.

Os primeiros estudos expressivos e experimentais de campo sobre o movimento de microorganismos no solo foram realizados por grupos de pesquisadores do Laboratório de Pesquisa de Engenharia Sanitária da Universidade da Califórnia, em Berkeley (USA). KRONE et al. (1957), em um projeto de três anos, injetaram água contaminada por esgotos em um aqüífero confinado à $29 \mathrm{~m}$ de profundidade, e monitoraram o poluente, utilizando uma rede de 23 poços de observação. As bactérias foram encontradas em distâncias de até $30 \mathrm{~m}$ do poço injetor na direção normal ao gradiente hidráulico. WESNER \& BAIER (1970) conseguiram resultados semelhantes na injeção de água poluída em poços, na Califórnia. Os cientistas observaram a presença constante de bactérias coliformes em poços de observação à $30 \mathrm{~m}$ de distância do poço injetor.

$\mathrm{Na}$ maioria dos casos, as bactérias sobrevivem de dois a três meses nos solos de climas temperados, apesar de terem sido mostradas taxas de sobrevivência de até cinco anos. A sobrevivência dos organismos no solo depende de vários fatores e é maior na estação chuvosa devido ao aumento da umidade no solo. Baixos pHs, além de aumentar a adsorção, são responsáveis pela redução na quantidade de nutrientes disponíveis para a bactéria. A quantidade de luz também é outro fator importante, já que a luz ultravioleta é bactericida (GERBA et al., 1975). Estudos de campo já mostraram que em aqüíferos heterogêneos de areia e cascalho, as bactérias podem ser transportadas por dezenas ou centenas de metros. O transporte de microorganismos em fraturas e/ou fissuras se dá ainda mais rapidamente, e as distâncias percorridas pelos organismos podem chegar a quilômetros (FREEZE \& CHERRY, 1979).

Os vírus, embora não possam multiplicar-se fora do hospedeiro, podem sobreviver por semanas e meses no meio ambiente, principalmente a temperaturas inferiores a $15^{\circ} \mathrm{C}$. KIM \& UNNO (1995) observaram concentrações de $10^{5}$ partículas infecciosas por litro de esgotos municipais brutos e, por conseguinte, concentrações semelhantes em solos onde esses esgotos são dispostos.

Sabe-se muito pouco a respeito da sobrevivência de vírus em águas subterrâneas, podendo-se, contudo, fazer estimativas aproximadas a partir de dados existentes sobre a sua sobrevivência em águas superficiais.

Diversos tipos de vírus entéricos necessitam de dois a cem dias para perder $99,9 \%$ de sua infecciosidade inicial, quando em suspensão 
em diferentes tipos de águas superficiais, com diferentes graus de poluição, a uma temperatura de $20^{\circ} \mathrm{C}$. O tempo de sobrevivência é amplamente determinado pela temperatura e pelo grau de contaminação, sendo mais longo em águas muito limpas e em águas altamente poluídas. Estudos realizados por LEWIS et al. (1986) com o poliovírus 1 e Coxsackievirus B-1, marcados radiativamente, indicaram que a desativação a temperaturas mais elevadas é devido aos danos causados ao ácido ribonucléico dos vírus.

Assim, a temperatura é o fator individual mais importante na eliminação dos vírus, também em águas subterrâneas, sendo que se pode esperar $99 \%$ de redução a uma temperatura de $20^{\circ} \mathrm{C}$ em dez dias, ainda que alguns enterovírus possam sobreviver por vários meses (BLANC \& NASSER, 1995).

O transporte de vírus em aqüíferos arenosos foi observado por BALES et al. (1989), logo que os sais solúveis destes vírus se dispersaram nos fluxos de água subterrânea, e sob determinadas condições químicas foram transportados a poucos metros de distância.

O processo mais intenso de retardamento do vírus no solo acontece por adsorção, porém este mecanismo de retenção do vírus nas paredes dos grãos de solo pode não ser permanente, ou seja, os vírus podem eventualmente desagregar as partículas sólidas, retornar à solução e continuar se movimentando. BALES et al. (1991) estudaram estes processos de adsorção dos vírus nas partículas sólidas e a reintegração dos vírus na solução utilizando colunas com esferas de silicato e bacteriófagos PRD-1 e MS-2. Uma vez que os vírus estavam aderidos às esferas, o estímulo à desagregação destes das esferas de silicato foi realizado com o aumento do $\mathrm{pH}$ da solução. Este trabalho ilustra a importância das perturbações químicas no transporte de biocolóides. Os autores afirmam que existem vários processos que contribuem para a aderência dos vírus e outros colóides nas partículas sólidas: atração e repulsão eletrostática, forças de Van der Waals, interações covalente-iônicas, ligações das moléculas de hidrogênio e efeitos hidrofóbicos.

BALES et al. (1995) estudaram o transporte do bacteriófago PRD-1, através de bactérias e microesferas de látex, em um aqüífero arenoso sob condições de gradiente natural. Sob as condições estudadas, não houve significante movimento do fago à frente do traço de sal. Maior sorção em $\mathrm{pH}$ inferior, aparentemente resultou em maior atenuação do bacteriófago, e uma aparente divergência vertical do vírus e plumas de traço de sal. Os três colóides e traço de sal (Br) moveram-se ao longo da mesma pluma. A atenuação do fago foi significante, com picos inferiores a $0,001 \%$ daqueles do $\mathrm{Br}$. A atenuação de bactéria e microesferas foi menor, com picos de concentrações aproximadamente de 10 e $1 \%$ daqueles do $\mathrm{Br}$, respectivamente. Por causa de suas características de transporte comparáveis e da boa sensitividade analítica, os bacteriófagos têm sido considerados bons traçadores do movimento da pluma biocolóide.

MATOS (2001), utilizando bacteriófagos como traçadores, verificou a ocorrência e transporte de microorganismos no aqüífero freático em cemitério cujo solo é formado por material de alteração das rochas graníticas, de caráter predominantemente argiloso. Os resultados mostram que as bactérias são transportadas alguns metros, diminuindo em concentração com o aumento da distância da fonte de contaminação. Os vírus parecem ter uma mobilidade maior que as bactérias, alcançando, no mínimo, algumas dezenas de metros no aqüífero freático da área estudada. Os vírus foram transportados, pelo menos, $3,2 \mathrm{~m}$ na zona não saturada até alcançar o aqüífero.

É de especial interesse para a proteção de poços saber os mecanismos que controlam o transporte de microrganismos nos aqüíferos, para dimensionar distâncias de proteção adequadas entre a fonte de contaminação, por exemplo, e poços de abastecimento. Os estudos de transporte, dos organismos nos meios porosos, no entanto, muitas vezes se restringem aos laboratórios, devido às dificuldades encontradas nos trabalhos de campo, pois nem sempre é economicamente viável montar uma rede de poços de observação, e é necessário ter um alto grau de controle devido ao grande número de parâmetros que podem influenciar o transporte dos organismos (temperatura, luz, $\mathrm{pH}$, existência de microrganismos e nutrientes, etc.). 


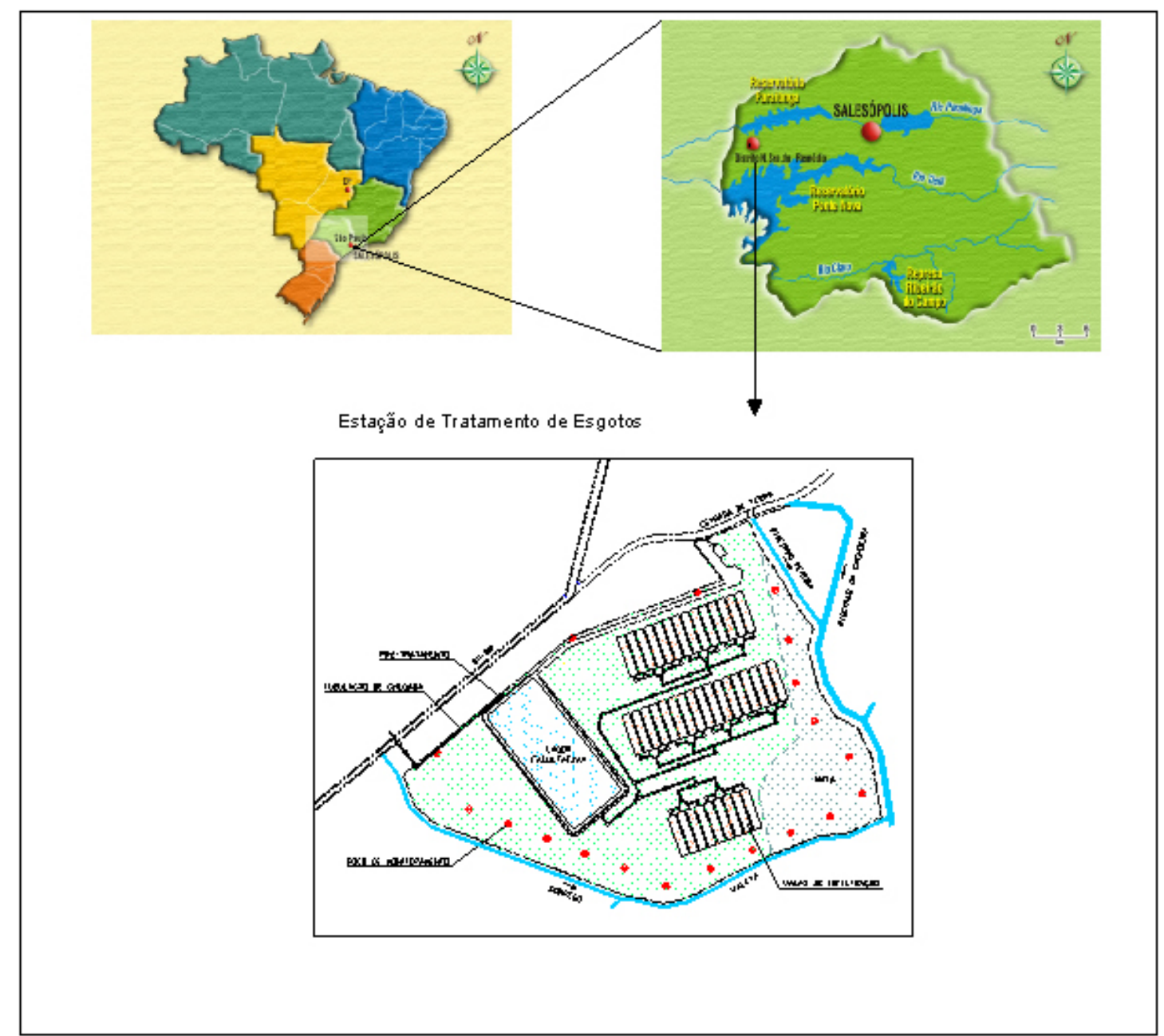

Figura 1 - Localização da área de estudo.

\section{LOCALIZAÇÃO DA ÁREA DE ESTUDO}

Dentro dos limites da área da Estação de Tratamento de Esgotos de Vila Nossa Senhora dos Remédios, município de Salesópolis (coordenadas: $23^{\circ} 31^{\prime} 55^{\prime \prime} \mathrm{S}$ e $45^{\circ} 50^{\prime} 51^{\prime}$ ' W), no Estado de São Paulo - Brasil, foi reservada uma área de aproximadamente, $6000 \mathrm{~m}^{2}$ próxima à lagoa facultativa primária, porém, distante das valas de infiltração que compõem o sistema de tratamento de esgotos da ETE, conforme Figura 1.

Obairro Vila Nossa Senhora dos Remédios onde está implantada a estação de tratamento de esgotos fica a $13 \mathrm{~km}$ da sede do município e pertence à bacia hidrográfica do Ribeirão Peroba, contribuinte do Rio Tietê. Suas águas estão classificadas, de acordo com a legislação ambiental, como pertencente à classe 2, ou seja, seu uso preponderante é para irrigação, pesca recreativa, atividades de lazer e abastecimento. Possui uma população aproximada de 800 habitantes que representa cerca de $20 \%$ do total do município.

$\mathrm{O}$ uso e a ocupação do solo restringe-se ao cultivo de hortaliças, sem qualquer atividade industrial local.

O município de Salesópolis tem $98 \%$ de sua área inserida em APA (Área de Proteção aos Mananciais).

\section{DIAGNÓSTICO AMBIENTAL DA ÁREA ESTUDADA}

Primeiramente, um pluviômetro e um tanque Classe A (evaporímetro) foram instalados no local para a caracterização climática da região. No decorrer de dois anos (maio/2003 a abril/2005) foram realizadas leituras diárias dos equipamentos obedecendo sempre o mesmo horário (entre 8:00 e 9:00 horas). Os resultados indicaram uma pluviometria média anual de $1250 \mathrm{~mm}$ e uma evaporação média anual de $996 \mathrm{~mm}$ no período considerado; típico de clima subtropical (Cwa) 
com inverno seco (temperaturas menores que $18^{\circ} \mathrm{C}$ ) e verão quente e úmido (temperaturas maiores que $22^{\circ} \mathrm{C}$ ).

Antes da intervenção no meio físico, inicialmente, foram perfurados 10 poços para conceituar o comportamento litológico. Os pontos foram escolhidos de forma a representar a área como um todo e, as amostras de solo coletadas foram analisadas granulometricamente. A classificação textural apresentou uma variação faciológica das lentes ao longo do perfil da área, com predominância de areias argilosas em $70 \%$ das amostras, $10 \%$ de argilas arenosas e $20 \%$ de areias grossas. Esta classificação permitiu inferir valores de condutividade hidráulica para sedimentos não consolidados, de acordo com FETTER (1988) e, assim, foi possível determinar a condutividade hidráulica predominante do aqüífero local no intervalo de $10^{-6}$ a $10^{-4} \mathrm{~cm} / \mathrm{s}$.

A análise química das amostras revelou baixos teores de matéria orgânica e carbonato, típico de solo aluvial.

As medidas do nível freático do aqüífero nos respectivos poços forneceram dados para a construção do mapa potenciométrico e a determinação das linhas de fluxo. Os resultados indicaram um aqüífero raso com profundidades variando entre $0,60 \mathrm{~m}$ a $2,00 \mathrm{~m}$ no local investigado.

Os dados topográficos e a investigação geofísica (sondagens elétricas e caminhamento eletromagnético) caracterizaram o aqüífero freático local quanto a sua estrutura e comportamento hidrodinâmico.

As análises físico-químico-bacteriológicas das águas do aqüífero apresentaram temperatura média de $18,4^{\circ} \mathrm{C}$; Eh (potencial redox) variando de $-6 \mathrm{mV}$ a $222 \mathrm{mV}$, onde a maioria das amostras evidencia um ambiente oxidante; a condutividade elétrica em média de $127 \mu \mathrm{S} / \mathrm{cm}$ e os parâmetros químicos analisados (íons e cátions) identificaram as águas subterrâneas locais como águas de baixa salinização (média de $80 \mathrm{mg} / \mathrm{L}$ ) e com ausência de coliformes fecais (ou termotolerantes).

Este estudo preliminar proporcionou um diagnóstico ambiental do local pesquisado que serviu de base para o estudo da infiltração de esgotos domésticos no solo, objetivo principal deste projeto.

\section{MATERIAL E MÉTODO}

Cinqüenta e cinco poços foram perfurados no local e distribuídos de tal forma que abrangessem totalmente a área de estudo. Por tratar-se de um aqüífero raso, considerou-se, no mínimo, um metro de aqüífero saturado, que, sujeito a flutuações sazonais do nível d'água, certamente, poderia dificultar a interpretação dos resultados, pois a pluma de contaminação originada da infiltração tem uma configuração longitudinal e vertical.

O esgoto bruto utilizado na pesquisa foi retirado diretamente da rede coletora em seu ponto de entrada na estação de tratamento, através de uma bomba de sucção, que possibilitou o enchimento de um reservatório de $2000 \mathrm{~L}$. Neste reservatório foi instalado um registro de saída em sua parte basal, de modo a controlar a vazão do esgoto que foi lançado em uma trincheira escavada no solo, com as seguintes dimensões: $0,30 \mathrm{~m}$ x 0,50m x $1,50 \mathrm{~m}$ (profundidade $\mathrm{x}$ largura $\mathrm{x}$ comprimento, respectivamente).

A taxa de infiltração da vala foi mantida em equilíbrio com a vazão do reservatório de modo a ocorrer uma infiltração contínua e sem transbordo.

A Figura 2 mostra esquematicamente, a metodologia de infiltração natural implantada na área de estudo.

A infiltração foi realizada em duas etapas distintas. A primeira, de curta duração, infiltrou 2000L de esgoto bruto no solo, no intervalo de tempo de 26 horas, com início em 01/09/2004, em período seco. A quantidade injetada inicialmente foi considerada ideal para atingir o objetivo da pesquisa, porém, ficou constatado, na prática, que esta quantidade seria insuficiente para se obter o resultado de todos os parâmetros almejados que pudessem servir de marcação, tendo em vista o alto poder de decaimento do contaminante ao longo do fluxo da pluma de contaminação no local de estudo e sua baixa velocidade de deslocamento. 


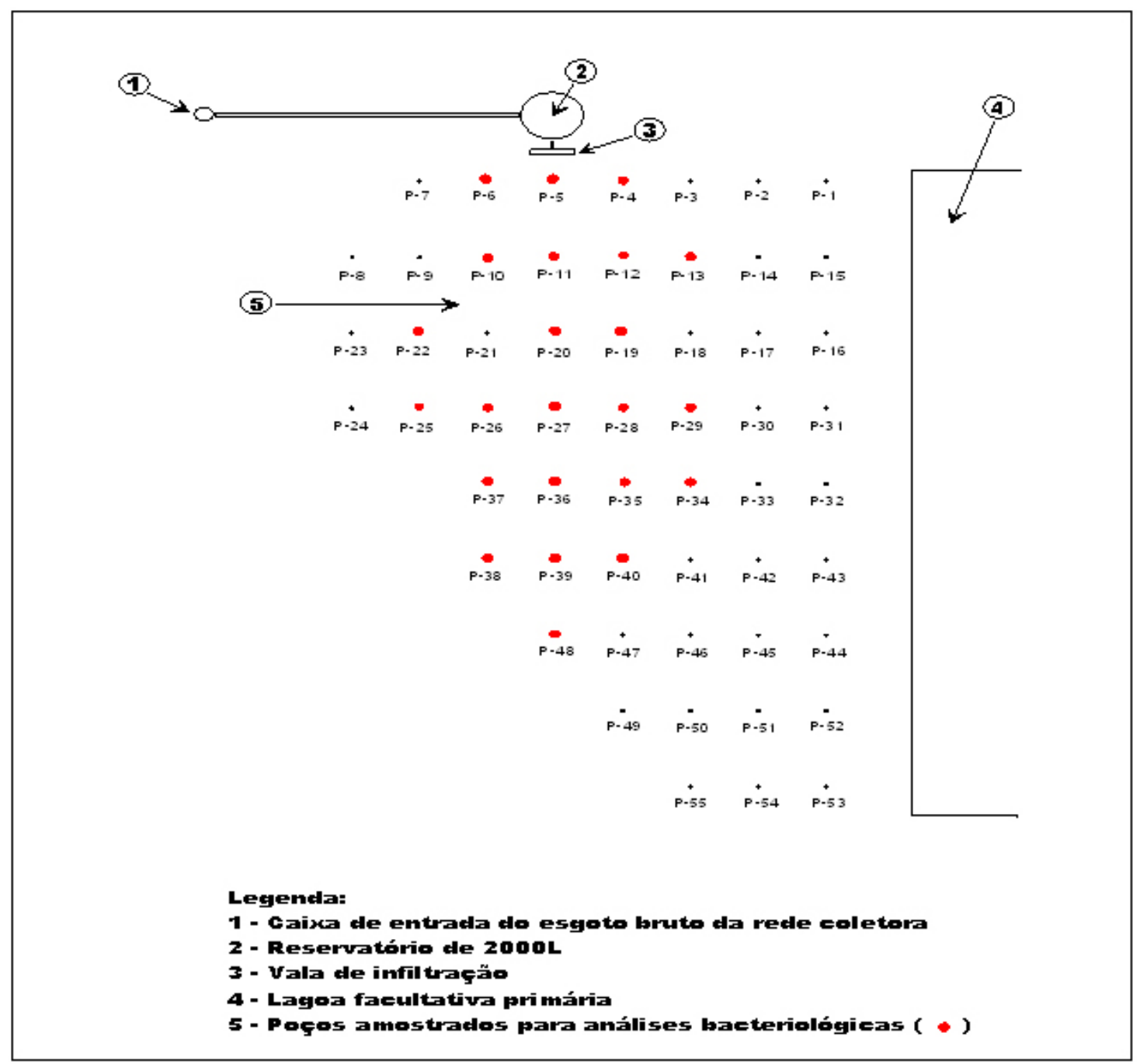

Figura 2 - Esquema da metodologia de infiltração.

Desse modo, foi realizada uma segunda infiltração, desta vez, 20000L de esgoto foram utilizados ao longo de quatro meses, (de 09/11/2004 a 15/03/2005). A diminuição da taxa de infiltração foi provocada pelo alto índice pluviométrico do período, responsável pela elevação do nível freático próximo à superfície ou alagando-a. Como o gradiente é o responsável pela variação da taxa de infiltração e, este passou a ser inexistente durante o período chuvoso, a taxa de infiltração deste ensaio não foi igual à do ensaio anterior, com velocidade de deslocamento bem inferior àquela.

Uma semana após o início da primeira infiltração, iniciou-se a coleta sistemática semanal das águas dos poços de monitoração, totalizando cinco semanas consecutivas para análise bacteriológica e química. Após este período foram coletadas amostras apenas para análise química, tendo em vista a resposta expressiva do decaimento bacteriológico no período considerado.

Os poços P-4, P-5, P-6, P-10, P-11, P-12, P-13, P-19, P-20 e P-28 foram escolhidos para serem amostrados durante essa primeira etapa, devido à proximidade com o ponto de infiltração.

$\mathrm{Na}$ segunda etapa do experimento, devido a problemas técnicos no laboratório como também pelo período de chuvas intensas, a coleta de amostras para análise bacteriológica teve início no primeiro dias após o término da infiltração do esgoto no solo, seguindo-se quatro semanas 
consecutivas de coletas.

Nesta etapa o número de amostras analisadas foi superior à etapa anterior e, os poços $\mathrm{P}-11$, $\mathrm{P}-12$, P-19, P-20, P-22, P-25, P-26, P-27, P-28, P-29, P-34, P-35, P-36, P-37, P-38, P-39, P-40 e P-48 foram escolhidos tendo em vista o sentido do fluxo subterrâneo local determinado pela potenciometria, a alta saturação do solo e uma maior abrangência do terreno.

Durante todo o período experimental, além das coletas de água e dos trabalhos geofísicos, foi feito um acompanhamento das possíveis alterações físicas das águas do aqüífero, através das medidas sistemáticas de nível, temperatura e condutividade elétrica.

\section{RESULTADOS}

As Tabelas 1 e 2 mostram os resultados das análises bacteriológicas dos poços amostrados na primeira e na segunda etapa do experimento, respectivamente.

Conforme mostra a Tabela 1, o P-5 é o poço cujos resultados indicam com melhor representatividade a chegada da pluma contaminante na primeira semana após o início da infiltração, o limite máximo de contaminação na segunda semana e o decaimento bacteriológico nas três semanas seguintes após o término da infiltração.

Os resultados bacteriológico e químico forneceram subsídios para a construção de gráficos que facilitaram a visualização e interpretação do comportamento dos parâmetros analisados.

Os dados bacteriológicos das amostras de água viabilizaram a construção dos gráficos das curvas de concentração de coliformes termotolerantes em função do tempo em cada poço amostrado. A Figura 3 apresenta dois desses resultados encontrados.

Concomitantemente, alguns elementos químicos analisados foram escolhidos para serem representados graficamente, tendo em vista sua tendência traçadora em casos de contaminação por esgoto doméstico. Para os elementos $\mathrm{Ca}, \mathrm{Mg}$,

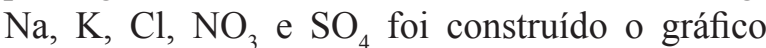
do teor de concentração em função do tempo, correspondente a cada poço amostrado durante o experimento.

Foi realizada uma interpretação detalhada em cada gráfico e verificou-se que os íons $\mathrm{SO}_{4}, \mathrm{Cl}$, $\mathrm{Ca}$ e $\mathrm{K}$ apresentaram dados mais representativos para interpretações do comportamento dos íons em solução ao longo de sua trajetória e cálculo da velocidade de deslocamento da pluma, baseados nos poços P-05, P-06, P-10, P-11, P-19, P-20 e P-28.

Dos quatro íons mais representativos citados anteriormente, $\mathrm{o} \mathrm{Cl}$ foi selecionado como marcador devido a sua baixa reatividade com o meio, sendo empregado em vários experimentos devido as suas características de preservação, também verificadas neste experimento.

A velocidade de deslocamento da pluma de contaminação foi calculada utilizando-se a distância entre dois poços e o tempo de chegada do íon $\mathrm{Cl}$ de um poço ao outro.

$\mathrm{O}$ resultado foi calculado levando-se em consideração as possibilidades de interação dos elementos com o meio e, chegou-se à seguinte velocidade média da pluma de contaminação de esgoto doméstico no local da pesquisa:

$V_{\mathrm{mp}}=7,67 \times 10^{4} \mathrm{~cm} / \mathrm{s} \mathrm{ou} 66,27 \mathrm{~cm} / \mathrm{dia}$

A sobrevivência de microrganismos em aqüíferos é influenciada por inúmeros fatores. Dentre eles, as atividades biológicas potenciais dos respectivos microrganismos, temperatura, $\mathrm{pH}$, propriedades químicas da água subterrânea, propriedades físico-químicas e mineralógicas do substrato mineral do aqǘfero e também, a correlação entre os microrganismos adicionados e a microfauna nativa do aqüífero.

Das interferências citadas, de acordo com a bibliografia consultada, foram consideradas as mais relevantes, como temperatura média das águas do aqüífero no período de injeção, $20^{\circ} \mathrm{C}$; $\mathrm{pH}$ médio de 6,5; propriedades químicas das águas subterrâneas com baixa concentração de sais e a composição litológica do aqüífero formada por areias quartzosas e de frações média a fina. O cálculo para determinar o decaimento bacteriológico foi baseado na diferença entre o teor máximo da concentração de coliformes termotolerantes na vala de infiltração $\left(1,1 \times 10^{7}\right.$ $\mathrm{NMP} / \mathrm{mL}$ ) em 01/09/2004 e o teor encontrado na amostra de 22/09/2004 referente ao P-05 (1,53 x $10^{3} \mathrm{NMP} / \mathrm{mL}$ ).

Esse poço foi escolhido tendo em vista seus resultados apresentarem maior confiabilidade em relação aos resultados dos poços amostrados após a segunda injeção, quando ocorreu o período de chuvas intensas, impossibilitando a infiltração do esgoto no subsolo, aumentando a diluição e a dispersão do mesmo sobre a superfície do terreno, descaracterizando assim, o resultado das amostras coletadas nessa segunda etapa da pesquisa. 


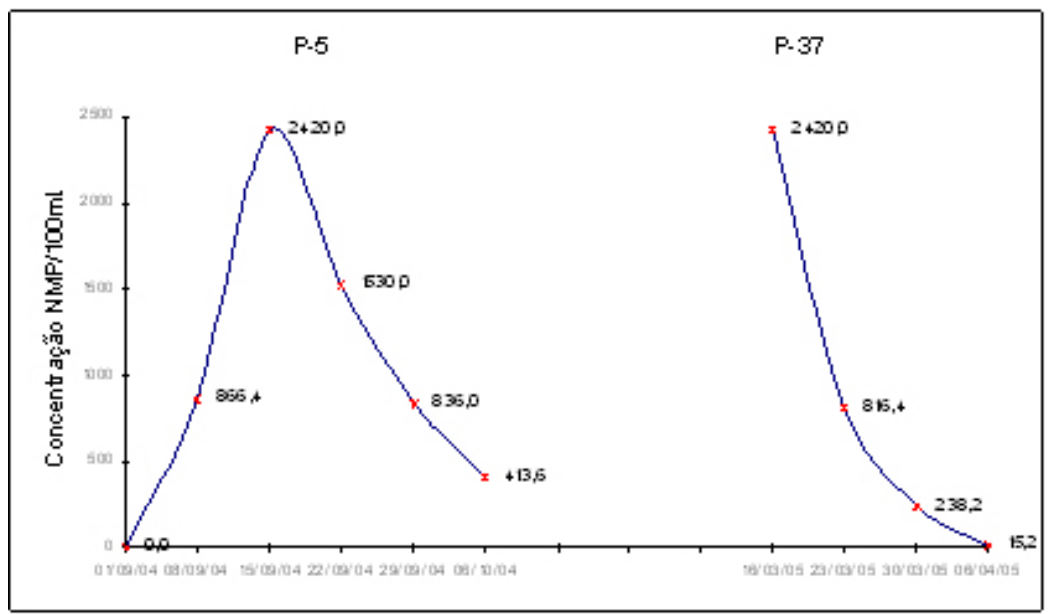

Figura 3 - Curvas de decaimento dos coliformes termotolerantes (P-5 e P-37).

Tabela 1 - Resultados das análises bacteriológicas ( $1^{\mathrm{a}}$ etapa do experimento)

\begin{tabular}{|c|c|c|c|c|c|}
\hline \multirow{3}{*}{ Poços } & \multicolumn{5}{|c|}{ Coliformes Fecais (NMP/100mL) } \\
\hline & \multicolumn{5}{|c|}{ Datas das coletas } \\
\hline & $\begin{array}{l}08 / 04 \\
2004\end{array}$ & $\begin{array}{l}15 / 04 \\
2004\end{array}$ & $\begin{array}{l}22 / 04 \\
2004\end{array}$ & $\begin{array}{l}29 / 04 \\
2004\end{array}$ & $\begin{array}{l}06 / 04 \\
2004\end{array}$ \\
\hline P-4 & 0,0 & 2,0 & 0,0 & 0,0 & 0,0 \\
\hline P-5 & 866,4 & $2420,0^{*}$ & 1530,0 & 836,0 & 413,6 \\
\hline P-6 & 13,4 & 0,0 & 0,0 & 0,0 & 0,0 \\
\hline P-10 & 0,0 & 0,0 & 0,0 & 0,0 & 0,0 \\
\hline P-11 & 0,0 & 0,0 & 0,0 & 0,0 & 0,0 \\
\hline P-12 & 0,0 & 0,0 & 0,0 & 0,0 & 0,0 \\
\hline P-13 & 0,0 & 0,0 & 0,0 & 0,0 & 0,0 \\
\hline P-19 & 0,0 & 0,0 & 0,0 & 0,0 & 0,0 \\
\hline $\mathrm{P}-20$ & 0,0 & 0,0 & 0,0 & 0,0 & 0,0 \\
\hline P-28 & 0,0 & 0,0 & 0,0 & 0,0 & 0,0 \\
\hline
\end{tabular}

Tabela 2 - Resultados das análises bacteriológicas ( $2^{\mathrm{a}}$ etapa do experimento)

\begin{tabular}{|c|c|c|c|c|}
\hline \multirow{3}{*}{ Poços } & \multicolumn{4}{|c|}{ Coliformes Fecais (NMP/100mL) } \\
\hline & \multicolumn{4}{|c|}{ Datas das coletas } \\
\hline & $\begin{array}{l}16 / \text { mar } \\
2005\end{array}$ & $\begin{array}{l}23 / \mathrm{mar} \\
2005\end{array}$ & $\begin{array}{l}30 / \mathrm{mar} \\
2005\end{array}$ & $\begin{array}{l}06 / a b r \\
2005\end{array}$ \\
\hline $\mathrm{P}-11$ & $2420,0 *$ & 920,0 & 360,0 & 158,6 \\
\hline $\mathrm{P}-12$ & $2420,0 *$ & 919,2 & 334,7 & 119,0 \\
\hline $\mathrm{P}-19$ & 1986,3 & 613,1 & 206,2 & 38,1 \\
\hline $\mathrm{P}-20$ & 787,3 & 318,1 & 45,7 & 0,0 \\
\hline $\mathrm{P}-22$ & 979,4 & 313,0 & 81,2 & 12,8 \\
\hline $\mathrm{P}-25$ & 1002,3 & 332,0 & 90,6 & 18,8 \\
\hline $\mathrm{P}-26$ & 1014,6 & 517,2 & 182,4 & 51,0 \\
\hline $\mathrm{P}-27$ & 1200,0 & 520,0 & 128,8 & 41,8 \\
\hline $\mathrm{P}-28$ & 1046,2 & 479,4 & 196,7 & 48,9 \\
\hline $\mathrm{P}-29$ & 483,9 & 99,7 & 13,0 & 4,1 \\
\hline $\mathrm{P}-34$ & 907,8 & 411,2 & 135,9 & 24,3 \\
\hline $\mathrm{P}-35$ & 1017,1 & 364,4 & 82,6 & 41,4 \\
\hline P-36 & 1242,9 & 371,3 & 74,1 & 14,1 \\
\hline P-37 & $2420,0^{*}$ & 816,4 & 238,2 & 15,2 \\
\hline
\end{tabular}

* 2420,0 NMP/100mL não indicam o valor real, mas o limite máximo de deteç̧ão pelo método do substrato enzimático, utilizado para verificação da presença de coliformes termotolerantes em amostras de água.

Considerando que a taxa de decaimento seja diretamente proporcional ao tempo, o período de três semanas (21 dias) resultou em um decaimento bacteriológico equivalente a $98,47 \%$.

Das interferências citadas, de acordo com a bibliografia consultada, foram consideradas as mais relevantes, como temperatura média das águas do aqüífero no período de injeção, $20^{\circ} \mathrm{C}$; $\mathrm{pH}$ médio de 6,5; propriedades químicas das águas subterrâneas com baixa concentração de sais e a composição litológica do aqüífero formada por areias quartzosas e de frações média a fina. $\mathrm{O}$ cálculo para determinar o decaimento bacteriológico foi baseado na diferença entre o teor máximo da concentração de coliformes termotolerantes na vala de infiltração $\left(1,1 \times 10^{7}\right.$ $\mathrm{NMP} / \mathrm{mL}$ ) em 01/09/2004 e o teor encontrado na amostra de 22/09/2004 referente ao P-05 (1,53 x $10^{3} \mathrm{NMP} / \mathrm{mL}$ ).

Esse poço foi escolhido tendo em vista seus resultados apresentarem maior confiabilidade em relação aos resultados dos poços amostrados após a segunda injeção, quando ocorreu o período de chuvas intensas, impossibilitando a infiltração do esgoto no subsolo, aumentando a diluição e a dispersão do mesmo sobre a superfície do terreno, descaracterizando assim, o resultado das amostras coletadas nessa segunda etapa da pesquisa. 
Considerando que a taxa de decaimento seja diretamente proporcional ao tempo, o período de três semanas (21 dias) resultou em um decaimento bacteriológico equivalente a $98,47 \%$.

\section{CONCLUSÕES}

O esgoto domiciliar de Vila dos Remédios foi caracterizado através de análises físico-químicabacteriológicas, apresentando teores de coliformes termotolerantes de $1,1 \times 10^{7} \mathrm{NMP} 100 \mathrm{~mL}$. Os resultados de análise química para os íons $\mathrm{Fe}$, $\mathrm{Mn}, \mathrm{Ca}, \mathrm{Mg}, \mathrm{Al}, \mathrm{Ba}, \mathrm{Sr}, \mathrm{Na}, \mathrm{K}, \mathrm{Ni}, \mathrm{Pb}, \mathrm{Cu}, \mathrm{Zn}$, $\mathrm{Cd}, \mathrm{Cr}, \mathrm{F}, \mathrm{SO}_{4}, \mathrm{Cl}, \mathrm{Br}, \mathrm{NO}_{3}$ e $\mathrm{HPO}_{4}$, indicaram baixas concentrações, com um máximo para $\mathrm{Na}$ de $73,00 \mathrm{mg} / \mathrm{L}$ e de $\mathrm{Cl}$ com $63,64 \mathrm{mg} / \mathrm{L}$. Dentro do limite de detecção utilizado, não foram encontradas concentrações de metais pesados neste esgoto, tipicamente domiciliar por tratar-se de rede coletora nova, com cerca de um ano de funcionamento, quando da coleta das amostras, e população atendida somente domiciliar.

A água subterrânea no local pesquisado possui baixa salinidade, apresentando maiores valores para os íons $\mathrm{Ca}(20,20 \mathrm{mg} /), \mathrm{Na}(26,50 \mathrm{mg} / \mathrm{L}), \mathrm{SO}_{4}$ $(40,03 \mathrm{mg} / \mathrm{L}), \mathrm{Cl}(31,39 \mathrm{mg} / \mathrm{L})$ e $\mathrm{NO}_{3}(19,20 \mathrm{mg} / \mathrm{L})$, denotando, assim, uma água típica de aqüíferos aluviais. Não foram detectados íons de metais pesados dentro do limite do sistema de análise.

As pesquisas geofísicas realizadas indicaram, para o local, um aqüífero freático raso, com profundidade variando de 0,60 a 2,00 metros, granulometricamente heterogêneo, com lentes mais arenosas ou argilosas, intercaladas, constatados pelos furos de sondagem para execução de 55 poços de monitoração e análise granulométrica das amostras extraídas.

A condutividade hidráulica local foi calculada a partir das análises granulométricas, dando um resultado de $10^{-6}$ a $10^{-4} \mathrm{~cm} / \mathrm{s}$, valores que se mostraram válidos com os cálculos, utilizando-se da concentração máxima de íons $\mathrm{Cl}$ nas amostras dos distintos poços de monitoração e as distâncias entre si, chegando-se então, a uma velocidade de deslocamento da pluma de $7,67 \times 10^{-4} \mathrm{~cm} / \mathrm{s}$.

O decaimento bacteriológico foi calculado pela concentração de microrganismos infiltrados e suas concentrações obtidas nos poços de monitoração ao longo do tempo do ensaio, cujos resultados comprovaram a cinética de decaimento, mostrandose conclusivos para eliminação de 98,47 por cento de coliformes termotolerantes, indicadores de contaminação fecal nas águas subterrâneas, no período de 21 dias.

\section{REFERÊNCIAS}

BALES, R.C., GERBA, C.P., GRONDIN, G.H., JENSEN, S. (1989) L. Bacteriophage transport in sandy soil and fractured tuff. Applied and Environmental Microbiology, v. 55, p. 2061-2067.

BALES, R.C., HINKLE, S. R., KROEGER, T.W e STOCKING, K. (1991) Bacteriophage adsorption during transport through porous media: chemical pertubations and reversibilty. Environmental Science Technology, v. 25, $\mathrm{n}^{\circ} 12$, p. 2088-2095.

BALES, R.C., LI, S., MAGUIRE, K. M., YAHYA, M. T., GERBA, C. P. e HARVEY, R. W. (1995) Virus and bacteria transport in a sandy aquifer, Cape Cod, MA. Ground Water, v. 33, n ${ }^{\circ}$ 4, p. 653-661.

BLANC, R. \& NASSER, A. (1995) Effect of effuent quality and temperature on the persistence of viruses in soil. Water Sci. Technol., 33: $237-42$.

BORREGO, J.; MORIÑO, M.; DE VICENTE, A.; CÓRNAX, R.; ROMERO, P. (1987). Coliphages as an indicator of faecal pollution in water. Its relationship with indicator and pathogenic microorganisms. Water Research.
21, 1473-1480.

CAMPOS, J. R. (1999) Tratamento de Esgotos Sanitários por Processo Anaeróbio e Disposição Controlada no Solo. Rio de Janeiro: ABES/PROSAB, p. 409 - 435.

CEBALLOS, B. S. O. (2000) Utilização de indicadores microbiológicos na tipologia de ecossistemas aquáticos de trópico semi-árido. São Paulo, 192 p. Tese (Doutorado em Microbiologia) - Instituto de Ciências Biomédicas, Universidade de São Paulo.

CONSTITUIÇÃO FEDERAL, Lei Federal $n^{\circ} 6938$ de 31/08/1981, Ministério do Meio Ambiente.

DANIEL, L. A. (2001) Métodos Alternativos de Desinfecção da Água - Programa de Pesquisa em Saneamento Básico - PROSAB, Edital 2, $1^{\text {a }}$ ed., São Carlos, SP, p. 18-23.

FETTER,C.W. (1988) Aplied Hydrogeology. In: CABRAL, J. Hidrogeologia - Conceitos $e$ Aplicações. Fortaleza, CPRM-LABHID-UFPE. c. 3, p. 35-51.

FREEZE, R.A., CHERRY, J.A. (1979) Ground Water. Prentice Hall, Inc., New Jersey.

GERBA, C. P., WALLIS, C. e MELNICK, J. L. 
(1975) Fate of wastewater bacteria and viruses in soil. Journal of the Irrigation and Drainage Division, 101, p. 157-174.

KIM, T. D. \& UNNO, H. (1995) The roles of microbes in the removal and inativation of viruses in a biological wastewater treatment system. Water Sci. Technol., 33: 243-9.

KOTT, Y.; BEN ARI, H.; VINOUR, L. (1978) Coliphages survival as viral indicator in various wastewater quality effluents. Pro Wat Tech. 10, 337-346.

KRONE, R. B., McGAUHEY, P. H. e GOTAS, H. B. (1957) Direct recharge og groundwater with sewage effluents. Journal of the Sanitary Engineering Division, 83 (SA4), p. 1325 -1335.

LEWIS, W.J. et al. (1986) O risco de poluição de lençol freático por sistemas de disposição local de esgotos. Brasília, Ministério do Desenvolvimento Urbano e Meio Ambiente/Programa das Nações Unidas para o Desenvolvimento.

MADIGAN, M. T.; MARTINKO, J. M.; PARKER, J. (1997) Brock biology of microorganisms. $8^{\text {th }}$ ed. New Jersey, Prentice Hall. 986 p.

MATOS, B. A. (2001) Avaliação da ocorrência e do transporte de microorganismos no aquífero freático do cemitério de Vila Nova Cachoeirinha, Município de São Paulo. 114 p. Tese (Doutorado) - Instituto de Geociências, Universidade de São Paulo.

MOORE, B. E. et al. (1981) Viral transport to ground water at a wastewater land application site. J. Water Pollut. Control Fed., 53: 1492-502.

PELCZAR JR., J.M.; CHAN, E.C.S.; KRIEG, N.R. (1980) Microbiologia. Vol. I. São Paulo, Mc Graw-Hill.

ROSE, J. B . (1990) Emerging issues for the microbiology of drinking water. In: Water, Engineering \& Management, p. 23-29.

SCHWARTZBROD, J. et al. (1986) Wastewater sludge: parasitological and virological contamination. Water Sci. Technol., 19 (8): 33-40. Apresentado ao 13th IAWPRC Biennial International Conference, Salvador.

WESNER, G. M., BAIER, D. C. (1970) Injection of reclaimed wastewater into confined aquifers. Journal of the American Water Works Association, 62, p. 203-210.

WESCOTT, D. \& AYRES, R. (1990) Critério de calidad de águas de riego, em riego com água residual municipal regenerada. Asano, $\mathrm{T}$. Editado por Universidad Politécnica de Cataluña. Barcelona. p. 33-66.

YATES, M. (1992) Biomonitors of environmental contamination. Encyclopedia of Microbology. Vol. I. Academic Press, Inc New York. p. 321-330. 